\title{
Technology, Creativity and the Media in Engineering China's Future
}

Cara Wallis, Technomobility in China: Young Migrant Women and Mobile Phones, New York: New York University Press, 2013. 264 pp. ISBN: 9780814795262

Michael Keane, Creative Industries in China: Art, Design and Media, Cambridge: Polity Press, 2013. 234 pp. ISBN: 9780745661018

Susan Shirk (ed), Changing Media, Changing China, New York: Oxford University Press, 2011. 281 pp. ISBN: 9780199751976

Reviewed by: Jonathan Sullivan, University of Nottingham, UK.

Political, economic and intellectual elites in China have for some time been in the grip of 'futurology' as they reflect on thirty years' of extraordinary economic development and ask 'what next'? China has a dream, in fact it has many visions of what it may become, reflecting robust debate and competition to define the nation's future course of reform and development (Callahan, 2013). On assuming the top party and state positions in October 2012 Xi Jinping quickly unveiled the China Dream (Zhonguomeng) as the maxim for his leadership. Although specification of what the dream will entail is yet to be fully explicated, one thing is certain: low-cost production and outsourcing more advanced economies' dirty jobs is neither the subject of China's dream nor is it any longer considered the means to delivering it. The 'world's factory' model that facilitated China's remarkable economic growth has come under pressure from all sides, as the party acknowledges its unsustainability and people deal with the consequences. Party elites and policymakers have taken significant steps toward a different and more sustainable model to secure long term growth and it is hoped that low-end manufacturing will give way to a service based economy and consumer culture facilitated by urbanization, migration and developing greater creative capacity. These plans are underpinned by the ambition to become an 'innovative nation' (chuangxinxing de guojia), to develop soft power resources to go with economic might, and to raise the 'quality' (suzhi) of the people. As the three books covered in this review essay demonstrate, technology, culture and the media are closely implicated, and closely controlled, in the Chinese state's quest for development.

\section{Mobile phones on the way to urban modernity}

Cara Wallis' exemplary ethnographic study of young migrant women working in the low level service sector (restaurants, beauty parlours, markets) in Beijing is an exploration of the cultural, social, aesthetic and economic dimensions of mobile phone use. More specifically it is an examination of the discourses, mental energies and emotions that form a "dynamic mobile phone assemblage" (p. 6). Building on the identification of ritual as a fundamental element of communication (Carey, 1989), this finely drawn book demonstrates how mobile phones, as symbols of reality, have become a key component in the constitution of selfhood, friendship and group solidarity, to the point where they are constitutive of migrant women's "becoming in the city" (p. 5). The study speaks to the broader processes of globalization, migration, marketization and 'informatization' that have been key components of China's 
reform era, and illuminates one role of technology in China's grand neoliberal project where individual merit, material wealth and consumption have become the hallmarks of 'socialism with Chinese characteristics'.

The 'quality' and 'civilization' (wenming) of the Chinese people has been seen as central to development since the beginning of China's encounter with western modernity in the early 20th Century. Chiang Kai-shek, Mao Zedong and Deng Xiaoping have all formulated such plans, with more recent guidelines and central party organizations established for 'building spiritual civilization', a 'civilized internet' etc. In contemporary China, as in the past, the main target is the rural population, which in social and cultural discourses is identified as lacking civilization vis-à-vis the cities: families of urban migrants who remain in the countryside are considered 'left behind' in more ways than one. Identifying 'who is rural' is complicated by the huge number of people, by some estimates 250 million, who have migrated to cities in search of economic and other opportunities in the past decade. The subjects of Wallis' study are young, female rural-to-urban migrants, known as dagongmei, a term that genders, classes and places them. Dagongmei has multiple, mainly negative, connotations, invoking rural, female, low class, callow, insecure, and temporary, which concretizes their liminality in the city. In the 'civilization narrative', low paid employment in the city is framed as an opportunity for migrants (especially women) to receive a social education, become more cultured, and learn the desired ways of urban modernity. Learning to use technology is closely implicated in the accompanying discourse about self-improvement through the acquisition of technological, linguistic, 'civilizing' skills. Wallis shows how migrant women internalize, enact and reproduce this duty via the mobile phone (p. 12), in accordance with the idea of self-improvement as a patriotic act and the more prosaic behavioural norms that prevail on urban women. For these migrant women a mobile phone is an important symbol of the urban modernity they desire and are expected to strive for.

There are more practical reasons for the importance of mobile phones. Rural-to-urban migrants tend to work long hours, have limited time-off and usually have highly circumscribed social lives. Removed from familiar social worlds, they are effectively "immobile" in the city. Mobile phones help overcome these alienating circumstances by allowing migrants to establish and navigate social networks, engage in forms of entertainment, participate in consumer culture and construct a 'modern self'. To capture this enabling facility, Wallis carefully develops the concept of immobile mobility, i.e. "a sociotechno means of surpassing spatial, temporal, physical and structural boundaries" (p. 6). A mobile phone represents agency to control personal resources, enhance self-worth and partake of entertainment amid an often humdrum existence punctuated by discrimination and loneliness (Pun, 2005). It is a lifeline to loved ones 'left behind' in the countryside and a way to nurture friendships in the city, although social networking tends to replicate class distinctions and cultural (especially guanxi) norms online: Immobile mobility does not imply or confer social mobility.

Given the psychological and practical importance of a mobile phone (for many migrants it is the only available telephonic or internet-enabled device), it is not surprising that migrant workers dedicate a substantial proportion of their financial resources to its acquisition. This is 
far removed from the image of fashionable middle classes lining up in city malls to buy the newest smartphone release. For migrants, buying a mobile phone has little to do with fashion and is anything but mindless materialism. In Wallis' study every interviewee described the mobile phone as "the first big urban purchase" (p. 73; my italics), entailing serious deliberation and sacrifice to the extent that every informant could recall the exact date, time and place of the purchase, how long it took to save up the money and even who accompanied them to buy it. ${ }^{1}$ As Qiu (2009) has described in his ground-breaking work on the "working class network society", the motivations and behaviours of this sector assign much greater importance to technology, and yet have been marginalized by the dominant image of young, well-off urban consumers with which technology use is frequently associated. Attached to migrants' mobile phones are "deep emotions and longings for modernity", a display of 'quality' as "a manifestation of their economic capital gained through labour" (p. 78) in a discursive context in which 'quality' is closely aligned to the ability to consume. Mobile ownership allows, however limited and illusory, access to the 'good life' promoted by the state as one of major components legitimating one-party rule, and allows them to "participate in a form of consumer citizenship in contrast to the legal and social citizenship they are denied in the city" (p. 26). Although Wallis' study uncovers potential for resistance on an individual (e.g. defying bosses' bans on bringing a phone to work) and collective basis (e.g. the organization of factory based protests), mobiles can also be used by bosses as a tool for surveillance, control and discipline. Ultimately, Wallis concludes that the "party state's modernization goals have become deeply internalized in the mind and bodies of China's citizens" (p. 180).

\section{Culture, creativity and the quest for soft power}

As Michael Keane puts it in his comprehensive survey of the "creative industries", the idea that creativity is essential for China's continuing development is uncontroversial in Chinese intellectual and political discourses. The most recent $\left(12^{\text {th }}\right.$ Five Year Plan pledged to develop technological innovation and cultural creativity, with the goal of becoming an 'innovative nation' and moving from 'made in China' to 'created in China'. The means to achieving creativity have been conceived in a particular way. The cultural industries (wenhua chanye) were heavily promoted in the $11^{\text {th }}$ Five Year plan (2005-2010), and in 2011 the Culture Minister set out plans for culture to become a pillar industry that would generate 5\% of GDP by 2016. This emphasis on GDP generation is emblematic of a "secularized and industrialized" (p. 2) system of cultural innovation, where policy levers drive accumulation and upgrading (shengji) with investment in infrastructure and physical clusters of cultural activities redolent of China's "factory product cities" which are defined by the commodity they produce (Jiang and Kuang, 2008). Although indigenous design and innovation is acknowledged as a source of added value and "the key to breaking out of the low cost production trap" (p. 150), creativity invokes political suspicion and is narrowly bounded. Politicized intellectual debates about liberalism, individualism and China's development

\footnotetext{
${ }^{1}$ The widespread availability of cheap, unbranded and increasingly sophisticated clones (shanzhaiji) is a major factor enabling low income migrants to acquire mobile phones, and an example of the kind of 'grassroots' innovation that Keane highlights as a manifestation of organic creativity (pp. 117-22).
} 
under the stewardship of the Party are manifest in tensions between cultural security, tradition and protectionism (both economic and in terms of Deng Xiaoping's warning and 1983 campaign against "spiritual pollution" (jingshen wuran)) on one hand, and creative freedoms, expressions of popular culture and novelty on the other. Traditional thinking suggests that “creativity generates 'good' and 'beautiful' outcomes: it harmonizes" (p. 52), but, as many creative individuals in China can attest, where creativity produces outcomes that are judged by the state to be lacking in these qualities, they are themselves 'harmonized' (bei hexie), a common euphemism for censorship, control and repression. The party justifies such constraining interventions by invoking its role as (self-proclaimed) protector of (self-defined) standards of public morality, tastes and spiritual health.

Circumspect and uncertain about how to deal with 'creativity', the state has acted with greater resolution in its focus on culture. Culture is conceived as a public resource and something from which party and nation can derive strength from. The term 'soft power' entered the official Chinese lexicon in 2006 when President Hu Jintao, in his address to the $17^{\text {th }}$ Party Congress, called for the need to "bring about a new upsurge in socialist cultural development, stimulate the cultural creativity of the whole nation and enhance culture as part of the soft power of country". Distinct from the protectionist impulse signified by the debate over 'national cultural security' prior to entry into the WTO in 2001, soft power was consistent with the 'going out strategy' that Chinese businesses had been encouraged to embark on since the 1990s. The desire to enhance Chinese soft power has been heavily influenced by the success of China's East Asian neighbours, particularly Japan, Korea and Taiwan, whose movies, music and other products have been enthusiastically adopted by Chinese citizens. It is no secret that China has under-performed in this 'soft power competition'. Attempts to portray China's 'great civilization' have generally fallen flat, even with audiences in China. Traditional cultural products, which fit party sanctioned great civilization narratives, have been revived in commercial forms, but spectacular motion pictures portraying Confucius, classic literary works and 'Red Classics' have failed to resonate with Chinese audiences enthralled by Korean pop, Taiwanese dramas and the like. By contrast, artists, filmmakers and other creative individuals like Jia Zhangke and Ai Weiwei have received critical acclaim outside of China, where there is generally a premium on work that challenges the status quo, but they have failed to reach audiences in China due to 'harmonization'. As early as 2005 there was an acknowledgement, by way of an editorial in the official People's Daily, of a 'cultural trade deficit crisis', but the lesson that soft power cannot be engineered in top-down fashion has not been learned. As Keane puts it, "East Asian pop culture is dynamic, youthful and devoid of overt political posturing: This is not the soft power formula that currently pertains in mainland China" (p. 193).

\section{Chinese media: Commercialization with control}

For Keane, media are the "defining piece of the creative industries jigsaw" (p. 177) and the contributions to Susan Shirk's edited volume demonstrate that the media are a crucial site and manifestation of the discursive and political contests evident in both Keane and Wallis' work. Relinquishing the monopoly on media from 1979 onwards and constructing the infrastructure for the internet from 1993 were strategies explicitly designed to help modernize the economy 
and help China become a technologically advanced nation. In the 1980s the government legalized advertising and cut subsidies to media outlets forcing them to earn revenue themselves, thus beginning the process of commercialization that has led to a crowded mediascape and transformed the information environment. Loosening control was conceived as making markets more efficient through the flow of information and improving governance through a watchdog function and mechanism for receiving feedback from the public. While necessary and laudable, Gang and Bandurski (p. 38) invoke the Chinese saying about Lord Ye, who professed to love dragons until confronted one, to describe the state's reaction to this process. Because it opens the possibility of political opposition "the CCP continues to monitor, censor and manufacture the content of the mass media", with the resolve and resources to prevent information reaching the public that might "inspire people to challenge party rule" (p. 3). And so, despite being rich in media choice, systematic censorship of the press and internet consistently places China near the bottom of various media freedom indexes.

From the inception of Beijing TV in 1958 (the forerunner to the national broadcaster CCTV), one of the major objectives was "disseminating knowledge and enriching peoples' lives" (p. 91), a pedagogical mission that CCTV maintains (Keane, p. 188). Since people from less developed areas, especially in the countryside, are particularly reliant on TV, and because the government wants to keep a rein on this demographic, TV is the most closely controlled medium and 'public opinion guidance' remains one of its major roles. CCTV's flagship primetime news program is the "primary TV propaganda machine" (p. 106) and local TV stations are required to broadcast it simultaneously on their main channels. Thus, basic cable subscribers in Beijing may have access to around 50 channels, but from 7-7:30 every night the majority will be broadcasting the same program. In 1982 the party decreed that important news should be released first on CCTV news at 7, and this norm continues today. In addition to agenda control, TV draws on the cultural industries to provide content for burnishing party narratives. Keane (p. 30) cites the example of a major 12-part documentary series broadcast on CCTV in 2006 on 'the rise of the great powers'. Each episode focused on events that neatly aligned with party narratives about social stability, industrialization, peaceful foreign relations and national unity. As many of the contributions to Shirk's volume attest, current conditions within the party and society are very different from those prevailing in 1988 when River Elegy (Heshang), a documentary series broadcast on CCTV, fundamentally critiqued China's developmental experience and narratives about its history.

The emergence under $\mathrm{Hu}$ Jintao of a media system that marries "commercialization with control" (p. 43) means that the media have two masters to serve: the party and the public. Media have to generate advertising revenue and keep within (oftentimes) vague, post-hoc and moving boundaries set by the party. All broadcasters feel ratings pressures, and not even CCTV is exempt from the imperatives of the financial bottom line. Programs with low ratings are cancelled, including those with a long history and pedagogical value, such as Reading Time, a literary review show originally broadcast on the main CCTV channel, later farmed out to the specialist CCTV 10, before being cancelled altogether in 2004. As Chinese society has become more complex and stratified, commercial media have sought to differentiate by 
serving different segments of a huge and heterogeneous audience. Reorganization of the TV market whereby each province is allowed one national satellite channel has led to informal specialization, e.g. Hunan TV is known for reality shows, Anhui TV dramas, etc. Ultimately, however, placating the simultaneous demands of political correctness and revenue generation, most commercial TV relies on duplicating, re-versioning and recycling low-value entertainment, much to the chagrin of the state with its exhortations for (a certain type of) creativity (Keane, p. 178).

The experience of two very different TV shows illustrates some of the contradictory dynamics surrounding the Chinese media. Supergirl (Chaoji Nüsheng) was a Pop Idol/American Idol clone broadcast to a national audience on Hunan Satellite TV between 2004 and 2006. The show was a terrific success, with an audience in the hundreds of millions, a corporate title sponsor etc. Its 'pure entertainment' product, and a subversive taste of democracy in the form of viewer voting, generated a huge amount of positive and negative attention. SARFT, the main regulatory body for TV programming (partly funded via compulsory donations from CCTV, which, not coincidentally, was losing revenues due to the popularity of Supergirl), decried it as vacuous and deplored the harsh criticism meted out to some contestants by the judges. CCTV itself held a seminar in July 2005 on 'the vulgar inclination of entertainment programs' and various party officials denounced the show. Although this criticism did not hurt viewing figures, the producers of Supergirl modified costuming, stage, design, song content etc, but this was not enough to save the show, which ended its run in $2006 .{ }^{2}$ Yet, it is not only commercial TV that faces constraints. Focus (Jiaodian Fangtan) is a short investigative journalism show produced and broadcast by CCTV shortly after the primetime news program. Running since 1994, its critical reports and exposés of corruption and other social ills are highly resonant in a country where corruption and officials' malfeasance is widespread. In his chapter, Miao Di (p. 110) cites data showing that over time the average proportion of reports cleared by multiple authorities and censors is around $25 \%$. He also invokes the (possibly apocryphal) saying that two lines regularly form outside the Focus studio: one for people wanting to bring corruption and other issues to the attention of the show's researchers, the other for officials attempting to get critical reports about themselves shelved. Although the show has a national audience and a remit to broadcast investigative reports, political sensitivities restrict the target of its investigations to low-level officials, akin to "killing a mosquito with a gun" (Liu, 2004).

\section{References}

Callahan W (2013) China Dreams: 20 Visions of the Future. New York: Oxford University Press.

Carey J (1989) Communication as Culture: Essays on Media and Society. New York: Routledge.

\footnotetext{
${ }^{2}$ An attempt to resuscitate the show was made in 2009 (under a different Chinese title which is translated as Supergirl), but this iteration has encountered similar difficulties.
} 
Jiang J \& Kuang X (2008) The Taxonomy of Contemporary Chinese Cities. Architectural Design, 78(5): 16-21.

Liu C (2004) Things You Don’t Know About Focus. China Youth Daily, 29, March.

Pun N (2005) Maid in China: Women Factory Workers in a Global Workplace. Durham: Duke University Press.

Qiu JL (2009) Working-Class Network Society: Communication Technology and the Information Have-Less in Urban China. Cambridge MA: MIT Press. 